\title{
木谷憲典 学位論文審査要旨
}

$\begin{array}{ccccc}\text { 主 査 } & \text { 林 } & & \text { 一 } & \text { 彦 } \\ \text { 副主査 } & \text { 井 } & \text { 藤 } & \text { 久 } & \text { 雄 } \\ \text { 同 } & \text { 領 } & \text { 家 } & \text { 和 } & \text { 男 }\end{array}$

\section{主論文}

High expression of EZH2 is associated with tumor proliferation and prognosis in human oral squamous cell carcinomas

（口腔癌におけるEZH2の高発現は腫瘍増殖および予後との関連性がある）

(著者：木谷憲典、尾崎充彦、田村隆行、山家健作、庄盛浩平、領家和男、井藤久雄) 平成21年 Oral oncology 45巻 39頁～46頁 


\section{学 位 論 文 要 旨}

\section{High expression of EZH2 is associated with tumor prol iferation and prognosis in human oral squamous cell carcinomas （口腔癌におけるEZH2の高発現は腫瘍増殖および予後との関連性がある）}

口腔の扁平上皮癌（Oral squamous cell carcinoma：OSCC）は口腔内で頻繁に見られる 癌であり、広範囲な局所浸潤やリンパ節転移のために最近でも患者の予後はあまり改善さ れていない。近年細胞増殖や細胞周期、アポトーシス経路を制御している因子の多くが予 後因子となるか研究されてきた結果、p53とKi-67が0SCCの悪性度の標識となるという報告 もあれば、否定的な報告もある。そこで新しい悪性度の標識となりうる、ヒストンH3のリ ジン27のメチル基の転移酵素であり、ヌクレオソームの変異やクロマチンの再構成を通じ て転写調節に重要な役割を持つポリコーム遺伝子群のイーゼットエイチツー (Enhancer of zeste homologue 2:EZH2) に着目した。EZH2の過剩発現は乳癌や胃癌、前立腺癌、肝細胞癌 等において悪性度との関連性が報告されているが、今まで口腔癌における報告はない。

そこで本研究において口腔の正常粘膜、異形成、OSCCにおけるEZH2蛋白の発現を免疫組 織化学的に検討し、Ki-67、p53、アポトーシスと比較するとともに、臨床病理学的因子と の関連や予後について解析した。

\section{方 法}

ヒトロ腔扁平上皮癌細胞株（HSC3、HSC4、SCCKN）を培養し、ウエスタンブロット法でEZH2 蛋白の発現を調べた。また、手術材料の非腫瘍部と腫瘍部におけるEZH2蛋白の発現を調べ た。正常口腔粘膜10部位、異形成50病変、0SCC102病変のホルマリン固定、パラフィン包埋 標本を用いて免疫組織化学的検討を行なった。病理診断はHE染色標本を用い、WHOの診断基 準(1997年)によってSCCを高分化、中分化、低分化の3種類に分類した。免疫組織化学はス トレプトアビジンービオチンーペルオキシダーゼ法にて行い、抗EZH2ポリクローナル抗体、 抗Ki-67モノクローナル抗体、抗p53モノクローナル抗体を用いた。それぞれ1000個以上の 細胞を数え、陽性細胞数をパーセンテージで表し、ラベリングインデックス (Labeling index:LI）とした。アポトーシスについてはTUNEL法を用い、TUNEL陽性細胞比率をアポト ーシスインデックス（Apoptosis index:AI）として表した。EZH2LIが50\%未満を低発現、 $50 \%$ 以上を高発現とし、EZH2蛋白発現と他のマーカーとを比較検討した。また、OSCC症例 のうち、StageII-IVの83症例について、EZH2、Ki-67、p53、AIの低発現群と高発現群にお ける生存率をKaplan-Meier法を用いて検討した。

\section{結 果}

ウエスタンブロット法で、扁平上皮癌細胞株 (HSC3、HSC4、SCCKN)においてEZH2蛋白の発 
現が見られた。手術材料においては、腫瘍部にEZH2蛋白の発現が見られた。一方、免疫組 織化学でEZH2蛋白は正常粘膜、異形成では基底層から有棘細胞層に、また、OSCCでは主に 癌胞巣辺縁の細胞核に発現していた。

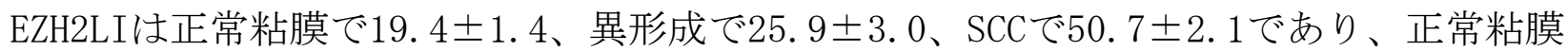
及び異形成とOSCCとの間に統計学的有意差を認めた $(\mathrm{P}<0.05)$ 。 OSCCでは高分化型で $40.7 \pm$

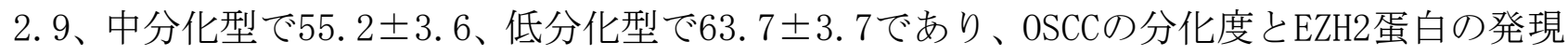
との間には有意な相関性が認められた $(\mathrm{P}<0.01)$ 。その他の検討した臨床病理学的因子にお いてEZH2蛋白の発現と分化度、腫瘍病期、腫瘍径、リンパ節転移において関連性があった。 また、OSCCにおけるEZH2蛋白の発現とKi-67とp53の間に相関がみられた（P<0.01）。OSCC の83症例（StageII-IV）におけるEZH2の高発現群は低発現群と比較して有意に予後不良で あった。

\section{考 察}

本研究ではヒト口腔正常粘膜、異形成、OSCCにおけるEZH2蛋白の発現を明らかにした。 ウエスタンブロット法ではOSCC細胞株や手術材料の腫瘍部にEZH2蛋白の発現を認めた。異 形成においてEZH2は基底細胞から有棘細胞層にまで分布し、Ki-67陽性増殖細胞の発現パタ ーンと類似しており細胞増殖活性を反映している可能性が示唆された。また、OSCCにおい てもEZH2陽性細胞の分布はKi-67陽性細胞の分布に類似し、文献上の乳癌や子宮癌、前立腺 癌や膀胱癌におけるEZH2発現と類似していた。さらにEZH2の過㮃発現は正常粘膜や異形成 よりも癌部において見られ、EZH2発現は口腔上皮や癌細胞において増殖活性と関連性があ ると示唆された。

EZH2発現は臨床病期、腫瘍径、リンパ節転移、特に分化度との相関が示され、EZH2高発 現はOSCCの高悪性度との関連性が示唆された。同様の結果は前立腺癌、乳癌、胃癌、肝細 胞癌、膀胱癌において報告がある。EZH2発現はKi-67、p53と正の相関関係があったが Kaplan-Meier法でEZH2のみが有意に予後が悪化した。この結果よりKi-67やp53よりも有用 な予後マーカーであると考えられた。

この論文は口腔癌において初めてEZH2発現と分化度、臨床病期、腫瘍径、リンパ節転移 との相関関係を示し、臨床病理学的因子を比較し、有用な予後マーカーとなる可能性を示 唆した。さらにポリコーム遺伝子群のEZH2は口腔癌診断治療における新しい予後マーカー となるだけでなく、近年、特にがん治療の標的分子となる可能性が示唆されており、分子 標的治療へ発展することが期待される。

\section{結 論}

口腔正常粘膜や口腔扁平上皮癌におけるEZH2蛋白の発現は細胞の分化および増殖に関 与すると考えられた。また、EZH2は口腔扁平上皮癌の予後因子となる可能性が示唆された。 